University of Wollongong

Research Online

Faculty of Business - Papers (Archive)

Faculty of Business and Law

2013

A critical assessment of the role of fashion in influencing the travel decision and destination choice

\author{
Clifford Lewis \\ University of Wollongong, cll105@uowmail.edu.au \\ Gregory M. Kerr \\ University of Wollongong, gkerr@uow.edu.au \\ Lois Burgess \\ University of Wollongong, lburgess@uow.edu.au
}

Follow this and additional works at: https://ro.uow.edu.au/buspapers

Part of the Business Commons

Research Online is the open access institutional repository for the University of Wollongong. For further information contact the UOW Library: research-pubs@uow.edu.au 


\title{
A critical assessment of the role of fashion in influencing the travel decision and destination choice
}

\begin{abstract}
While the word fashion is often associated with clothing and accessories, the objective of this paper is to argue that as a broader concept, fashion has relevance to tourism. It is argued that fashion can influence behaviour and both the decision to travel, and the destination selected may in some cases be a fashion statement by the traveller. Following discussion as to the meanings and explanations of fashion, a conceptual model is presented having the purpose of demonstrating how fashion can be a moderating variable in the travel decision and destination selection process. The model proposes the influence of fashion on leisure tourism, and is a foundation for future studies to further investigate fashion and tourism.

Keywords

era2015

Disciplines

Business

\section{Publication Details}

Lewis, C., Kerr, G. M. \& Burgess, L. (2013). A critical assessment of the role of fashion in influencing the travel decision and destination choice. International Journal of Tourism Policy, 5 (1/2), 4-18.
\end{abstract}




\title{
A Critical Assessment of the Role of Fashion in Influencing the Travel Decision and Destination Choice
}

\begin{abstract}
While the word fashion is often associated with clothing and accessories, the objective of this paper is to argue that as a broader concept, fashion has relevance to tourism. It is argued that fashion can influence behaviour and both the decision to travel, and the destination selected may in some cases be a fashion statement by the traveller. Following discussion as to the meanings and explanations of fashion, a conceptual model is presented having the purpose of demonstrating how fashion can be a moderating variable in the travel decision and destination selection process. The model proposes the influence of fashion on leisure tourism, and is a foundation for future studies to further investigate fashion and tourism.
\end{abstract}

Keywords: 'fashion theory', 'leisure travel', 'decision making', 'tourism', 'symbolism', 'destination choice'. 


\section{Introduction}

Leisure tourism is a discretionary activity (Leiper, 1979). Given available time and resources, an individual can choose whether to travel, and consequently make a choice of where to travel. Not only is the demand discretionary, supply is increasing as more places attempt to position themselves as tourist destinations (Echtner and Ritchie, 2003). Being a fashionable destination may be a point of difference in the travel decision and destination selection process.

Although the importance of being a fashionable destination may appear to be logical, to our knowledge, little attention has been given to this application. The objective of this paper is to introduce the concept of fashion as being relevant to tourism. This is achieved by discussing extant literature and presenting a conceptual model proposing that fashion can be a moderating variable in the travel decision and destination selection processes. It is intended that this work be the foundation for more extensive studies of the relationship between fashion and tourism. First, literature on destination selection with a focus on destination choice models is presented. This is followed by a discussion of fashion literature, the definition of fashion, and the relevance of fashion to tourism.

\section{Destination Choice Models}

A number of models have been developed to explain destination choice. Hwang et al. (2006) categorised these as being either choice-set models, decision-net models, multi-destination travel models and general travel models. Choice-set models focus attention on the funnelling process individuals use to select a single destination from a larger subset. Um and Crompton (1990) for instance, proposed a two-stage approach to destination choice; the first being the evolution of an awareness set into a narrower evoked set; and the second stage being the selection of a destination from the evoked set. 
Decision-net models examine the travel decision at an aggregate level analysing the different aspects of travel planning and the relation between them. Dellaert, Ettema and Lindh (1998) for example, discussed a multi-faceted tourist travel decision process that involves sequential choices for different aspects of a single trip, and the constraints that may influence those decisions. Their findings highlighted that the choice of different aspects of travel represented a sequential, yet interrelated decision process that made up the total travel decision process.

Multi-destination models are used to explain processes involved where more than one destination is considered and visited on a single trip. Lue, Crompton and Fesenmaier (1993) for example, identified five different spatial patterns; four of which involved visits to multiple destinations. These included the en-route pattern where the traveller visits multiple destinations en-route to a main destination; the base camp pattern where the traveller visits multiple destinations always returning to a base destination between each visit; regional-tour pattern where the traveller visits several destinations in a region and finally the trip-chaining pattern that involves a touring vacation that includes several destinations of focus.

Finally, general travel models are based on consumer theory and focus on the process that individuals follow in their destination choice. Moutinho (1987) for example, examined how consumers behave within a tourism context. The author examined factors that influenced the tourist's behaviour and found that aspects such as culture, reference groups, the relationships between individuals and their environments, perceived risks, and family affected the individual's decision processes. It should be noted that due to the emphasis placed on reference groups, general travel models are relevant to the argument presented in this paper.

Despite extensive research and explanations of destination choice, there are a number of shortcomings. These include the assumption of a rational consumer (Lewis, Kerr and Pomering, 2010), an emphasis on the functional benefits of tourism (Decrop, 2010), and 
many research approaches that tend to replicate existing perspectives rather than seek new and more relevant explanations (Franklin and Crang, 2001). A novel approach suggested here is to treat not only the decision to travel (whether to), but also the destination selected (where to), as being influenced by fashion. Literature on fashion is now discussed.

\section{The Meaning of Fashion}

Fashion is a behavioural complex underlying all stylistic innovations (Robinson, 1958). In academic literature, there are several definitions of fashion. These definitions can be classified into three categories, that is, as: a behaviour, a form of emulation, and being appropriate for a particular situation (see: Kane, 1923; Robinson, 1961; Sproles, 1974; 1979; Solomon and Rabolt, 2004). In this paper, fashion is summarised as being 'a particular behaviour that is popular within one's peer group because it is perceived as being symbolically appropriate within that group for a given time or situation'. This definition is consistent with Back's (1985) claim that fashion is a function of society and the period.

Fashion is a central component of almost all daily activities (O'Cass, 2001). Fashion has a role in science, art, education and literature (Blumer, 1969; Sproles, 1981) and is relatively public in nature (Reynolds, 1968). Although fashion is often related to clothing and accessories (Solomon and Rabolt, 2004), its meaning and application is broad, even to the extent that it has relevance to leisure travel. Given the public nature of tourism, particularly leisure travel, it is likely that fashion can have an influential role. Prior to discussing the role of fashion in tourism, literature on how a fashion spreads or diffuses throughout society is discussed. 


\section{The Diffusion of Fashion}

As early as 1893, Foley proposed that fashions were luxury products afforded by the upperclass of society. Academic interest in fashion gained prominence after the seminal paper by sociologist Simmel ([1904] 1957) who argued that fashions are first adopted by those higher in social status and then trickle-down to lower socio-economic groups. Known as the trickledown effect of fashion, this perspective of fashion diffusion proposes that fashion is driven by the influence of competing forces of distinction and emulation. Subordinate groups attempt to adopt status symbols of groups above them in an effort to enhance their social status. Simultaneously, the upper-class strives to ensure that they are not imitated by those below them and adopt newer fashions.

The trickle-down perspective of fashion diffusion gained wide acceptance until King's (1969) rebuttal where he argued that once introduced, fashions spread simultaneously across social strata. Called the mass-market theory, King (1969) argued that mass-communication combined with mass-production impeded any systematic vertical flows of fashion. This allows fashion to diffuse across socio-economic boundaries replacing high fashion with mass-fashion in a trickle-across effect.

Also in 1969, Blumer, argued against the trickle-down perspective suggesting that fashions spread by a process of collective-selection. The theory argues that fashions emerge from a process of negotiation wherein many new styles compete for acceptance by consumers, with those styles that closely represent consumer tastes, gaining social acceptance. Similarly, Solomon and Rabolt (2004, p.19) suggested that "fashions tend to sweep the country... [and suddenly] everyone is doing the same thing or wearing the same style or colours." Emphasising the influence of symbols, they defined collective selection as a form of social conformity where certain symbols or meanings are chosen over others. 
In the 1960's, fashions were seen to be influenced more by counter-cultural, sub-cultural and diverse ethnic groups rather than by the upper-class (Kaiser, Nagasawa and Hutton, 1995). Similarly, Sproles (1981) proposed the sub-cultural leadership theory suggesting that fashions may be initiated by sub-cultures based on their creativity, artistic excellence, or relevance to current lifestyle. This style is then noticed by the larger population who may adopt it. A similar effect was noted in tourism by Loker-Murphy and Pearce (1995) while studying backpackers in Australia. They argued that young tourists have taken the lead in diffusing tourism destinations particularly by redirecting tourism flows to third world countries in Asia and the Pacific.

In 1974, Sproles attempted to develop a conceptual framework for what by then was known as 'fashion theory'. According to Sproles (1974), fashion was perceived as being a vague network of creative ideas, rather than structured and interrelated set of concepts and principles. He also noted that fashions may be influenced by industry, suggesting that industry (supply) has a role in persuading, if not coercing the direction of fashion. This point should be kept in mind when the implications of this research to tourism marketers are discussed later in the conclusion section of this paper.

Kaiser, Nagasawa and Hutton (1995) in an effort to explain why fashions continue to change, concluded that the novelty afforded by appearance-modifying commodities (or new fashion) contributed to looks that were both familiar, and confusing, and so were symbolically ambiguous. Because society needs to process this ambiguity, it leads to the development of rich constructions of meaning. Through a negotiation of meaning(s), commodities previously with ambiguous meanings, develop into fashionable styles. Symbolism and meaning appear to be relevant to fashion. 
Aksan et al. (2009) proposed that symbolic-interaction is the process by which meanings emerge from the reciprocal interaction of individuals within a social environment. The theory proposes that purchasing is dependent on what the object represents to the individual and others whom they associate with (Leigh and Gabel, 1992). Elaborating on this, Leigh and Gabel (1992) discussed the process through which objects achieve and maintain symbolic value. They suggested that once an individual decides to identify with a group, she/he must take note of what certain products and symbols mean for that group. Once identified, the individual will then emulate behaviour (including consumption) perceived as being favourable by the relevant group. This communicates the individual's membership with that group, and helps distinguish between groups. A similar argument was proposed by Crane (1999) who suggested that fashions are adopted to conform to the values and norms expressed within a group. This is similar to the general travel models discussed in Section 2. Other authors have since looked at fashion through the guises of conspicuous consumption and status consumption. These are now discussed and contrasted with fashion.

Veblen ([1899] 1931) was perhaps the first author to propose that goods may be consumed due to the meaning inherent in them. Having coined the term conspicuous consumption to define consumption or purchase of products for status and prestige, Veblen ([1899] 1931, p.36) suggested: "In order to gain and hold the esteem of men, it is not sufficient merely to possess wealth or power. The wealth or power must be put in evidence, for esteem is awarded only on evidence." The evidence may be through the objects purchased and consumed by the individual. In applying conspicuous consumption to tourism, Phillips and Back (2011, p.585) defined a conspicuous destination as "a destination where tourists believe they can be observed and/or judged by significant others" and argued that conspicuous consumption can influence destination choice. Phillips and Back (2011) suggested that a destination can be 
more conspicuous than another, and found that factors such as "interpersonal mediation, status demonstration and materialistic hedonism" (p.590) influence destination choice.

O'Cass and McEwen (2004, p.34) defined status consumption as "the behavioural tendency to value status and acquire and consume products that provide status to the individual". They argue that status consumption is a reflection of the consumer's desire to gain prestige from the acquisition of status-laden products and brands, and propose that consumers at every class have the desire to consume for social status. Status consumption may therefore play a role in the trickle-down effect of fashion as status brands are consumed by those lower in social hierarchy to communicate an improvement in their social status. Langer (1997) defines two categories of status brands: pinnacle brands and premium brands. Pinnacle brands act as icons of excellence and symbolise success and wealth, while premium brands are respected and elite products that are not ridiculously overpriced. By their nature, status brands are able to command premium prices (Eastman, Goldsmith and Flynn, 1999). Such brands may be used as means to an end, such as making a desired impression on others via the brand's symbolism (O'Cass and Frost, 2002). In regard to tourism, Gilbert (1990) argued that destinations can be classified as being commodity areas or status areas. He suggests commodity area destinations do not differentiate themselves well and are easily substitutable. Status area destinations are better differentiated, less substitutable and have more product attributes (both functional and symbolic) and consumers are more likely to pay higher prices.

Although status and conspicuous consumption have considerable theoretical overlaps (see: Eastman, Goldsmith and Flynn, 1999; O'Cass and Frost, 2002), status consumption is different from conspicuous consumption. Status consumption emphasises the personal nature of owning status brands while conspicuous consumption focuses on putting wealth into evidence and therefore displaying possessions (O'Cass and McEwen, 2004). Further, while social display is a prime function of fashion consumption, it is argued that fashion is a higher 
order factor. Fashion products may be consumed to communicate a statement to others including wealth and commercial success among other potentially mutually exclusive messages that the individual may want to communicate. Fashions may be adopted for sexual excitement, expression of ego, expression of personality attitudes, mood enhancement, the demonstration of personal creativity (Sproles, 1985) or to fit in with certain roles (Forsythe, Butler and Kim, 1991).

Regardless of the perspective of fashion diffusion taken, there is general agreement that a fashion starts with an individual or group in society. The dissemination of fashion seems to be similar to that of an innovation and, as such, Rogers' (1962) Innovation Adoption Model has relevance. Rogers defined diffusion as the process by which an innovation is communicated among members of a social system. He suggested that diffusion of an innovation can be displayed as a bell-shaped curve over time. Commencing with the innovators, an innovation expands throughout a population with a progressively higher percentage of a population adopting the innovation until a smaller and remaining percentage, the laggards take up the innovation.

A theory similar to Rogers' (1962) Innovation Adoption Model was introduced in tourism by Plog (1974). Considered as a seminal tourism model (Litvin, 2006), Plog (1974) suggested that different tourist personalities visit destinations over time. First, allocentrics discover a new tourist destination. These places are often untouched by commercialisation. Allocentrics exhibit similar characteristics to fashion leaders or innovators. Once allocentrics return to their home location, they communicate their experience, encouraging near-allocentric persons to visit the destination. As demand increases, destinations develop their tourist facilities. During this phase, the number of allocentric visitors declines due to the loss of the destination's naturalness. Eventually, the destination enters its decline phase attracting near- 
psychocentric and psychocentric visitors who prefer visiting destinations that are familiar and well known. Psychocentrics are comparable to fashion followers or laggards.

Christaller (1964) discussed the effect of marketing on making destinations popular and suggested that through marketing, islands and forgotten places are developed into resort destinations that become imperative to visit. With reference to artists, Christaller (1964, p.103) noted that:

"Painters search out untouched and unusual places to paint ... the place develops as a socalled artist colony. Soon a cluster of poets follows, kindred to the painters: then cinema people, gourmets, and the jeunesse doree. The place becomes fashionable and the entrepreneur takes note. The fisherman's cottage, the shelter-huts become converted into boarding houses and hotels come on the scene. Meanwhile the painters have fled and sought out another periphery - periphery as related to space, and metaphorically, as 'forgotten' places and landscapes. Only the painters with a commercial inclination who like to do well in business remain; they capitalize on the good name of this former painter's corner and on the gullibility of tourists. More and more townsmen choose this place, now en vogue and advertised in the newspapers. Subsequently the gourmets, and all those who seek real recreation, stay away. At last the tourist agencies come with their package rate travelling parties; now, the indulged public avoids such places. At the same time, in other places the same cycle occurs again; more and more places come into fashion, change their type, and turn into everybody's tourist haunt."

An important point is made at this juncture. Both Rogers' (1962) and Plog's (1974) models refer to total populations, that is, the population of users of an innovation over time and the population of tourists visiting a destination over time. Christaller (1964) also suggested that as destinations increase in popularity they come 'into fashion'. What may be important is a focus on the populations of segments, as their consumption lifecycle of a product may differ over time. Christaller (1964, p.103) actually makes this point when he explains that a destination "becomes fashionable [with artistic people - similar to Sproles (1981) subcultural leadership theory] and the entrepreneur takes note". He then explains as the consumption of the destination increases, it becomes unfashionable with the artists and the like who "have fled and sought out another periphery". While the destination becomes more popular with the tourism masses (the population of tourists) and is seen overall as 
fashionable, it may be unfashionable with some segments. It is argued that the fashionability of a place is not as simple as one bell-shaped curve. More likely, there are multiple segments, or indeed subcultures, which have different interpretations in regard to a destination's level of fashionability. Given the emphasis placed on symbolism in fashion literature, the concept of symbolism as it relates to the purchase of goods and services is now discussed.

\section{Product Symbolism}

Products, have functional and symbolic benefits which can influence a customer's perceptions and behaviour towards it (Keller, 1993; Bath and Reddy, 1998). While functionality may satisfy practical needs, symbolism carried by products may contribute to a consumer's identity and image (Grubb and Grathwohl, 1967). Such symbolism may even be a means of distinguishing the social class of the consumer (Levy, 1959). The sign value of a purchase (and use) can be a statement that conveys a message about the individual (Dimanche and Samdahl, 1994). These symbols acquire meaning through inter-personal socialization processes that begin in childhood (Solomon, 1983; Colton, 1987), and may differ based on a point of reference (Miller, McIntyre and Mantrala, 1993) and culture (Solomon, 1983). Taking a marketing perspective, Levy (1959: p.118) suggested that "people buy things not only for what they can do, but also for what they mean". Therefore, consumption of certain products depends on the social meaning inherent in them (Solomon, 1983).

Mick et al. (2004) argued that product attributes contribute to the meaning associated with the object. Studying the meaning of clothing, McCraken and Roth (1989) found that different ensembles of clothing had a different meaning. Mick et al. (2004) suggested that marketers should continually try to strategically develop and facilitate meanings that contribute positively to the product image. It is in this regard, that brands and brand management are 
important, in not only identifying and differentiating a product, but communicating meanings about the product. These meanings can relate to both functional and symbolic benefits of a product. When purchased, these product meanings can be used by individuals to define themselves (McCracken, 1986), and communicate who they are and where they are positioned in their society (Thurot and Thurot, 1983). The symbolic benefit gained by the purchase and consumption of some products may outweigh the functional benefits that the product delivers. In this regard, the decision to travel, when compared to other options, and the destination selected, from a group of destinations, may be symbols which can be used to communicate a person's identity and status in society.

\section{Symbolism and Tourism}

In the context of tourism, destinations have functional and symbolic attributes (Hankinson, 2004). Although the functional components have been noted to play a key role in assisting the customer to develop the initial destination choice set (Balakrishnan, Nekhili and Lewis, 2011), leisure travel may be motivated by other symbolic elements and be viewed as a form of symbolic consumption aimed to enhance one's self image and esteem (Dimanche and Samdahl, 1994). The very decision to travel or not to travel may be subject to the symbolic benefits or costs (for example 'I would like to be seen there' as against 'I would not like to be seen there'). In some cases, a tourist may place a low functional value on a destination but may give a higher weighting to the perceived symbolic value (Todd, 2001). Visitors from different segments may place different meanings on their travel experience (Colton, 1987). A particular destination may therefore carry different meanings or symbols - some favourable some not so - for different individuals. It is the symbolism associated with the act of leisure travel and the destination(s) visited that may contribute to making a destination fashionable. Interestingly, as people may purchase products to define 'who they are' their definition of 
their 'fashionable self' will almost require them to partake in fashionable activities, perhaps travel, and visit fashionable destinations. This is similar to the Diderot effect as discussed by McCraken (1988) who argues that the purchase of one object may cause the individual to purchase other items that have a similar meaning to develop their self identity. It is in this regard that the act of travel and the destination selected has associated with it symbolism which can be deemed by the travellers as being fashionable.

\section{Fashion and Tourism}

Blumer as early as 1968 argued that the study of fashion is limited due to the "false assumption" that fashion is only of trivial or peripheral significance and falls within the realm of irrationality, thus being beyond mainstream human group life (p.275). More recently, Kaiser, Nagasawa and Hutton (1995) noted that critical elements of fashion such as aesthetic codes and social meaning have received very little attention. Although conspicuous consumption has been considered in relation to tourism, despite the time which has elapsed, there remains a paucity of research linking fashion with consumer decision making in tourism. This study addresses this gap, and in doing so, extends the application of fashion theory and discusses its relevance to a field of practice beyond clothing and accessories to which it is most commonly applied. Given the increasing competition between destinations, understanding this application of fashion, could enable destination marketing organisations to gain an advantage by positioning their destination as a fashionable place.

The influence of fashion on destination choice is to some extent supported by tourism literature. This includes studies such as Christaller (1964) which was discussed previously, Greenwood (1976), Stansfield (1978), Corneo and Jeanne (1999) and Wilson and Richards (2008). Although these studies do not investigate the role of fashion in tourism, they allude to its relevance. 
Greenwood (1976, p.133) discussed how tourism was initially considered as being restricted to the upper-class, who, while on their summer holiday shrouded their lives in "conspicuous privacy". He argued that due to improved accessibility and more affordable accommodation, the twentieth century has seen a collapse of the upper-class monopoly of tourism in favour of a more active middle-class. The influence of the trickle-down and mass-market fashion effects on tourism can therefore be argued. Greenwood (1976) also pointed out that in tourism, fashion and vogues played a major role.

Stansfield (1978) while studying the legalisation of gambling in Atlantic City noted that during the city's development, day-trippers who visited but did not stay overnight, perceived the fancy hotels at the destination to be symbols of the American Dream of upward mobility. He also discussed how places develop into resort destinations. Once developed, the idea of 'new' pulls American tourists who usually are from upper-socio economic groups. As the cost of visiting the place reduces, middle-income groups arrive to experience the destination's well publicised attractions. Eventually, as the number of lower-income tourists increases, the upper-income groups that had originally dominated the area move to new recreational environments. This view is consistent with the propositions of the trickle-down theory of fashion as introduced by Simmel ([1904] 1957). Stansfield (1978) also reiterates Greenwood's (1976) claim of tourism being driven by fashion and the desire for novelty.

Corneo and Jeanne (1999) in their study of the influence of segmented communication on fashion behaviour, used the choice of a holiday destination as an example of behaviour affected by fashions. Finally, Wilson and Richards (2008) while studying backpackers found that they considered fashionable destinations as being undesirable but still regarded them as something that needed to be experienced. 


\section{Leisure Travel and Destination Choice as Fashion}

Mintzberg (2005) suggested that as researchers, our responsibility is to provide multiple explanations to the same phenomenon. This he argued may be done through selecting theories that are perceived to be useful, and testing their relevance to different phenomena. To our knowledge, apart from some mention of fashion and tourism (e.g. Corneo and Jeanne 1999), no previous study has attempted to study the relevance of fashion theory to tourism.

In tourism, Sirakaya and Woodside (2005) suggest that research on destination selection tends to focus more on the psychological variables of destination choice and not on social variables, including, family and significant others, who may play an important role in influencing destination selection. They call for a new theory of destination selection by arguing that although most tourism models accept the influence of others on the decision maker, they tend to treat the decision maker as if they were in a vacuum, and do not address the influence of social interaction on the decision making process. Since tourism is a social activity involving family, relatives, friends and other reference groups, a different approach is needed that also considers the role of emotions on the choice process. Even as early as 1990, Smith was calling for tourism researchers to formulate and test new models about the tourism system rather than relying on traditional or untested hypothesis on how tourism works.

Klenosky (2002) proposed that destinations may be means to achieving ends. Similarly, Urry (1990) suggested that destinations are often not consumed because they are intrinsically superior but, because of the taste or status they communicate. Graburn (1983) also argued that changes in tourist styles are not random but represent aspects of class competition, prestige hierarchies and the succession of changing lifestyles. Styles are chosen with reference to previous experience of the individual's reference group, or in regard to other classes or groups that the individual wishes to emulate (Graburn, 1983). The decision to travel followed by the destination choice may therefore represent the individuals effort to 
manage their social identity (Lewis, Kerr and Pomering, 2010) by adopting behaviours that communicate an appropriate message.

The interactive nature of an individual's social group exerts a strong influence on behaviour (Crompton, 1981). If a destination is perceived as being fashionable with one's peer group, visiting that destination may communicate membership of a group or indicate an aspiration in being a member of a group. This has a similar effect to the trickle-down theory of fashion if the individual is interested in being a member of a higher socio-economic group (Simmel, [1904] 1957) or the sub-cultural leadership theory of fashion if the individual wants to identify with a particular group (Field, 1970). This notion is also consistent with the general models of destination choice discussed previously in this paper.

Central to this paper is the premise that leisure travel and destination choice can be behaviours which are deemed to be fashionable. It seems that, to be in fashion, an item or behaviour needs to convey some type of symbolism or meaning. Based on our argument that fashion is 'a particular behaviour that is popular within one's peer group because it is perceived as being symbolically appropriate within that group for a given time or situation', it is argued that fashion is a moderating variable (see Baron and Kenny, 1986), first in deciding the use of disposable income and recreational time (whether to) and second if travel is chosen, in deciding on the destination (where to). Figure 1 shows the conceptual model suggesting how fashion may influence the decision to travel (1) and the choice of destination (2). 


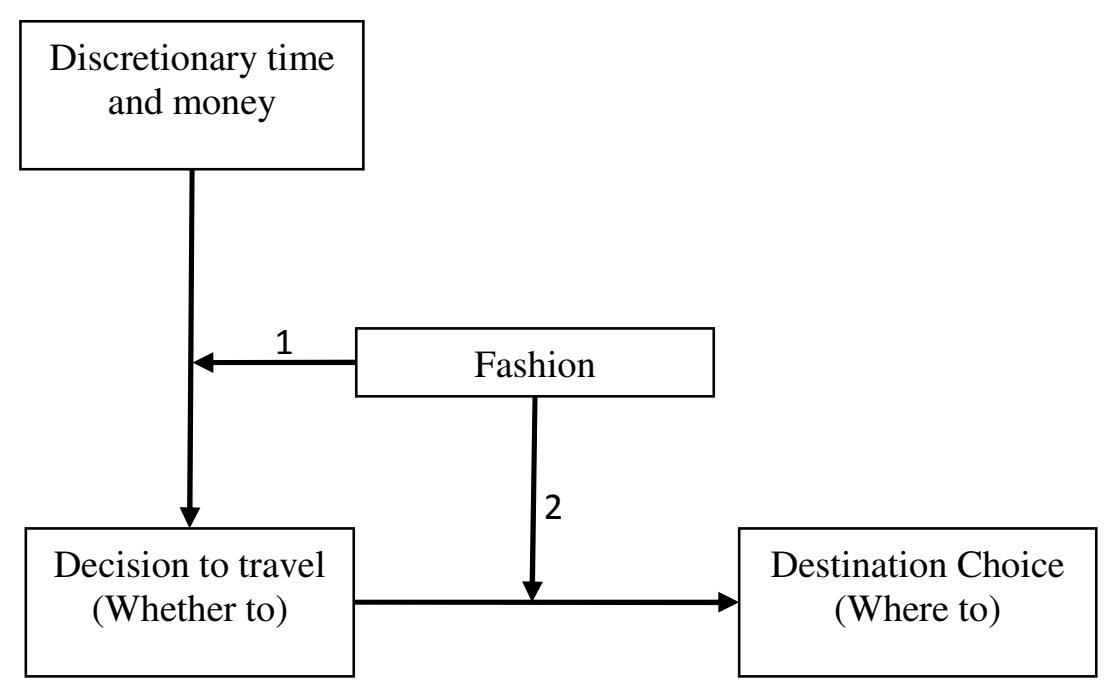

Figure 1: Influence of Fashion on Leisure Travel

It is argued that given available time and money, an individual is free to decide whether to travel or pursue other options. The decision may be based on an activity perceived as being fashionable within an existing or aspirational peer group. Volo (2009) argued that tourism represents only one way free time can be used. As discussed in this paper, if the individual decides to travel, the destination choice may also be dependent on what is fashionable. It is argued that the fashionability of the destination may play a role in developing choice sets. In doing so, it helps simplify the destination choice process. The destination selected may be dependent on the reference group that the individual identifies with, that is, what might be fashionable.

\section{Conclusion}

It is argued that a probabilistic relationship may exist between fashion and the decision to travel and destination choice. Dul and Hak (2008) explained that a probabilistic relationship exists if the change in the value of an independent variable causes a change in the value of a dependent variable in a predicted way. Therefore, the more fashionable the act of travel and a specific destination is perceived to be within one's peer group, the more likely are members of that group to travel and visit that destination. 
Although this paper presents a conceptual model only, based on the literature on fashion, it is argued that there is value in treating the acts of leisure travel and destination choice as fashion statements. This paper proposes another explanation to understanding tourist behaviour. While fashion may not explain all leisure travel and destination decisions, it is likely to influence the decisions of many consumers. Arguably, even tourists who avoid visiting 'fashionable' destinations, are perhaps doing so because, such behaviour is perceived as being fashionable within their reference group.

The objective of this paper is to discuss the relevance of fashion to tourism. This has been achieved by a review and reflection of relevant literature and the development of a conceptual model. Future research planned will aim to empirically validate this model. If confirmed, an understanding of the role of fashion will be of value to tourism marketers. This may be important at two levels. First national tourism organisations may need to focus not just on destination marketing, including place promotion, but to ensure that leisure travel is deemed to be a fashionable activity (shown as ' 1 ' in Figure 1). Second at a destination level, marketers may need to understand and work towards ensuring that their destination is one deemed to be fashionable by members of their target markets (shown as '2' in Figure 1). In addition, the issue arises that a destination may not be fashionable with the population of tourists, but only with the populations of segments of tourists. This may mean that a destination is deemed to be not fashionable or unfashionable by other segments. Fashionability therefore may be an attractor to some segments, while an inhibitor to other. This paper has provided a foundation for future studies into the relevance of fashion to tourism. It is hoped that other researchers will make contributions in addition to ours to this field of investigation. 


\section{References}

Aksan, N., Kisac, B., Aydin, M. and Demirbuken, S. (2009) 'Symbolic Interaction Theory', Procedia Social and Behavioural Sciences, Vol. 1 No. 1, pp. 902-904.

Back, K. (1985) 'Mordernism and Fashion: A Social Psychological Interpretation', in M. Solomon (Ed.), The Psychology of Fashion, Lexington Books, New York, pp. 3-14.

Balakrishnan, M., Nekhili, R. and Lewis, C. (2011) 'Destination Brand Components', International Journal of Culture, Tourism and Hospitality Research, Vol. 5 No. 1, pp. 4-25.

Baron, R. and Kenny, D. (1986) 'The Moderator-Mediator Variable Distinction in Social Psychological Research: Conceptual, Strategic, and Statistical Considerations.', Journal of Personality and Social Psychology, Vol. 51 No. 6, pp. 1173-1182.

Bath, S. and Reddy, S. (1998) 'Symbolic and Functional Positioning of Brands', Journal of Consumer Marketing, Vol. 15 No. 1, pp. 32-43.

Blumer, H. (1968) 'Sociological Analysis of Fashion'. Paper presented at Twenty-fourth Conference of College Teachers of Textiles and Clothing. 30th October-2nd November. Palmer House, Chicago, Illinois.

Blumer, H. (1969) 'Fashion: From Class Differentiation to Collective Selection', Sociological Quarterly, Vol. 10 No. 3, pp. 275-291.

Christaller, W. (1964) 'Some Considerations of Tourism Location in Europe: The Peripheral Regions -Under Developed Countries- Recreational Areas', Papers in Regional Science, Vol. 12 No. 1, pp. 95-105.

Colton, C. (1987) 'Leisure, Recreation, Tourism: A Symbolic Interactionism View', Annals of Tourism Research, Vol. 14 No. 3, pp. 345-360.

Corneo, G. and Jeanne, O. (1999) 'Segmented Communication and Fashionable Behaviour', Journal of Economic Behavior and Organization, Vol. 39 No. 4, pp. 371-385.

Crane, D. (1999) 'Diffusion Models and Fashion: A Reassessment', The Annals of the American Academy of Political and Social Science, Vol. 566 No. 1, pp. 13-24.

Crompton, J. (1981) 'Dimensions of the Social Group Role in Pleasure Vacations', Annals of Tourism Research, Vol. 8 No. 4, pp. 550-568.

Decrop, A. (2010) 'Destination Choice Sets: An Inductive Longitudinal Approach', Annals of Tourism Research, Vol. 37 No. 1, pp. 93-115.

Dellaert, B., Ettema, D. and Lindh, C. (1998) 'Multi-faceted tourist travel decisions: a constraint-based conceptual framework to describe tourists' sequential choices of travel components ', Tourism Management, Vol. 19 No. 4, pp. 313-320.

Dimanche, F. and Samdahl, D. (1994) 'Leisure as Symbolic Consumption: A Conceptualization and Prospectus for Future Research', Leisure Sciences, Vol. 16 No. 2, pp. 119-129. 
Dul, J. and Hak, T. (2008) Case Study Methodology in Business Research, Elsevier, Oxford.

Eastman, J., Goldsmith, R. and Flynn, L. (1999) 'Status Consumption in Consumer Behaviour: Scale Development and Validation', Journal of Marketing Theory and Practice, Vol. 7 No. 3, pp. 41-52.

Echtner, C. and Ritchie, J. R. B. (2003) 'The Meaning and Measurement of Destination Image', The Journal of Tourism Studies, Vol. 14 No. 1, pp. 37-48.

Field, G. (1970) 'The Status Float Phenomenon: The Upward Diffusion of Innovation', Business Horizons, Vol. 13 No. 4, pp. 45-52.

Foley, C. (1893) 'Fashion', The Economic Journal, Vol. 3 No. 11, pp. 458-474.

Forsythe, S., Butler, S. and Kim, M. S. (1991) 'Fashion Adoption: Theory and Pragmatics', Clothing and Textiles Research Journal, Vol. 9 No. 4, pp. 8-15.

Franklin, A. and Crang, M. (2001) 'The trouble with tourism and travel theory? ', Tourist Studies: an international journal, Vol. 1 No. 1, pp. 5-22.

Gilbert, D. (1990) 'Strategic Marketing Planning for National Tourism', Tourist Review, Vol. 45 No. 1, pp. 18-27.

Graburn, N. (1983) 'The Anthropology of Tourism', Annals of Tourism Research, Vol. 10 No. 1, pp. 9-33.

Greenwood, D. J. (1976) 'Tourism as an Agent of Change: A Spanish Basque Case', Annals of Tourism Research, Vol. 3 No. 3, pp. 128-142.

Grubb, E. L. and Grathwohl, H. L. (1967) 'Consumer Self-Concept, Symbolism and Marketing Behavior: A Theoretical Approach.', Journal of Marketing, Vol. 31 No. 4, pp. 2227.

Hankinson, G. (2004) 'The Brand Images of Tourism Destinations: A Study of the Saliency of Organic Images', Journal of Product and Brand Management, Vol. 13 No. 1, pp. 6-14.

Hwang, Y., Gretzel, U., Xiang, Z. and Fesenmaier, D. (2006) 'Travel Destination Choice Models', in D. Fesenmaier, H. Werthner and K. Wober (Eds.), Destination Recommendation Systems: Behavioural Foundations and Applications, CAB International, Oxfordshire, United Kingdom, pp. 17-29.

Kaiser, S., Nagasawa, R. and Hutton, S. (1995) 'Construction of an SI Theory of Fashion: Part 1. Ambivalence and Change', Clothing and Textiles Research Journal, Vol. 13 No. 3, pp. 172-183.

Kane, W. (1923) 'The Psychology of Fashion', America, Vol. 29 No. 12, pp. 269-270.

Keller, K. (1993) 'Conceptualizing, Measuring, and Managing Customer-Based Brand Equity', Journal of Marketing, Vol. 57 No. 1, pp. 1-22.

King, C. (1969) 'Fashion Adoption: a Rebuttal to the "Trickle Down" Theory', in J. McNeal (Ed.), Dimensions of Consumer Behavior, Appleton-Century-Crofts, New York, pp. 
Klenosky, D. (2002) 'The "Pull" of Tourism Destinations: A Means-End Investigation', Journal of Travel Research, Vol. 40 No. 4, pp. 396-403.

Langer, J. (1997) 'What Consumers Wish Brand Managers Knew', Journal of Advertising Research, Vol. 37 No. 6, pp. 60-65.

Leigh, J. H. and Gabel, T. G. (1992) 'Symbolic Interactionism: Its Effects on Consumer Behaviour and Implications for Marketing Strategy', The Journal of Consumer Marketing, Vol. 9 No. 1, pp. 27-38.

Leiper, N. (1979) 'The Framework of Tourism -Towards a Definition of Tourism, Tourist, and the Tourist Industry', Annals of Tourism Research, Vol. 6 No. 4, pp. 390-407.

Levy, S. (1959) 'Symbols for Sale', Harvard Business Review, Vol. 37 No. July-August, pp. 117-124.

Lewis, C., Kerr, G. and Pomering, A. (2010) 'Self-identity and social norms in destination choice by young Australian travellers.', Tourist Studies: an international journal, Vol. 10 No. 3, pp. 265-283.

Litvin, S. (2006) 'Revisiting Plog's Model of Allocentricity and Psychocentricity... One More Time', Cornell Hotel and Restaurant Administration Quarterly, Vol. 47 No. 3, pp. 245-253.

Loker-Murphy, L. and Pearce, P. L. (1995) 'Young Budget Travellers: Backpackers in Australia', Annals of Tourism Research, Vol. 22 No. 4, pp. 819-843.

Lue, C., Crompton, J. and Fesenmaier, D. (1993) 'Conceptualization of Multi-Destination Pleasure Trips', Annals of Tourism Research, Vol. 20 No. 2, pp. 289-301.

McCracken, G. (1986) 'Culture and Consumption: A Theoretical Account of the Structure and Movement of the Cultural Meaning of Consumer Goods', Journal of Consumer Research, Vol. 13 No. 1, pp. 71-84.

McCracken, G. (1988) Culture and Consumption: New Approaches to the Symbolic Character of Consumer Goods and Activities, Indiana University Press, Indiana.

McCracken, G. and Roth, V. (1989) 'Does Clothing Have a Code? Empirical Findings and Theoretical Implications in the Study of Clothing as a Means of Communication', International Journal of Research in Marketing, Vol. 6 No. 1, pp. 13-33.

Mick, D. G., Burroughs, J. E., Hetzel, P. and Mrannen, M. Y. (2004) 'Pursuing the Meaning of Meaning in the Commercial World: An International Review of Marketing and Consumer Research Founded on Semiotics', Semiotica, Vol. 152 No. 1/4, pp. 1-74.

Miller, C., McIntyre, S. and Mantrala, M. (1993) 'Toward Formalizing Fashion Theory', Journal of Marketing Research, Vol. 30 No. 2, pp. 142-157.

Mintzberg, H. (2005) 'Developing Theory about the Development of Theory', in M. Hitt and K. Smith (Eds.), Great Minds in Management: The Process of Theory Development, Oxford University Press, New York, pp. 355-372. 
Moutinho, L. (1987) 'Consumer Behaviour in Tourism', European Journal of Marketing, Vol. 21 No. 10, pp. 5-44.

O'Cass, A. (2001) 'Consumer Self-Monitoring, Materialism and Involvement in Fashion Clothing', Australasian Marketing Journal, Vol. 9 No. 1, pp. 46-60.

O'Cass, A. and Frost, H. (2002) 'Status Brands: Examining the Effects of Non-ProductRelated Brand Associatios on Status and Conspicuous Consumption', Journal of Product and Brand Management, Vol. 11 No. 2, pp. 67-88.

O'Cass, A. and McEwen, H. (2004) 'Exploring Consumer Status and Conspicuous Consumption', Journal of Consumer Behaviour, Vol. 4 No. 1, pp. 25-39.

Phillips, W. and Back, K. (2011) 'Conspicuous Consumption Applied to Tourism Destination', Journal of Travel and Tourism Marketing, Vol. 28 No. 6, pp. 583-597.

Plog, S. (1974) 'Why Destination Areas Rise and Fall in Popularity', Cornell Hotel and Restaurant Adminstration Quarterly, Vol. 14 No. 4, pp. 55-58.

Reynolds, W. (1968) 'Cars and Clothing: Understanding Fashion Trends', Journal of Marketing, Vol. 32 No. 3, pp. 44-49.

Robinson, D. (1958) 'Fashion Theory and Product Design', Harvard Business Review, Vol. 36 No. 6, pp. 126-138.

Robinson, D. E. (1961) 'The Economics of Fashion Demand', The Quarterly Journal of Economics, Vol. 75 No. 3, pp. 376-398.

Rogers, E. (1962) Diffusion of Innovations, 3rd, The Free Press, New York.

Simmel, G. ([1904] 1957) 'Fashion', The American Journal of Sociology, Vol. 62 No. 6, pp. 541-558.

Sirakaya, E. and Woodside, A. (2005) 'Building and Testing Theories of Decision Making by Travellers', Tourism Management, Vol. 26 No. 6, pp. 815-832.

Smith, S. (1990) 'A Test of Plog's Allocentric/Psychocentric Model: Evidence from Seven Nations', Journal of Travel Research, Vol. 28 No. 4, pp. 40-43.

Solomon, M. (1983) 'The Role of Products as Social Stimuli: A Symbolic Interactionism Perspective', Journal of Consumer Research, Vol. 10 No. 3, pp. 319-329.

Solomon, M. and Rabolt, N. (2004) Consumer Behaviour in Fashion, Prentice Hall, New Jersey.

Sproles, G. B. (1974) 'Fashion Theory: A Conceptual Framework', Advances in Consumer Research, Vol. 1 No. 1, pp. 463-472.

Sproles, G. B. (1979) Fashion: Consumer Behaviour Toward Dress, Burgess Publishing Company, Minneapolis, Minnesota. 
Sproles, G. B. (1981) 'Analyzing Fashion Life Cycles -Principles and Perspectives', Journal of Marketing, Vol. 45 No. 4, pp. 116-124.

Sproles, G. B. (1985) 'Behavioural Science Theories of Fashion', in M. Solomon (Ed.), The Psychology of Fashion, Lexington Books, New York, pp. 55-70.

Stansfield, C. (1978) 'Atlantic City and the Resort Cycle: Background to the Legalization of Gambling', Annals of Tourism Research, Vol. 5 No. 2, pp. 238-251.

Thurot, J. M. and Thurot, G. (1983) 'The Ideology of Class and Tourism: Confronting the Discourse of Advertising', Annals of Tourism Research, Vol. 10 No. 1, pp. 173-189.

Todd, S. (2001) 'Self-concept: A Tourism Application', Journal of Consumer Behaviour, Vol. 1 No. 2, pp. 184-197

Um, S. and Crompton, J. L. (1990) 'Attitude Determinants in Tourism Destination Choice', Annals of Tourism Research, Vol. 17 No. 3, pp. 432-448.

Urry, J. (1990) 'The Consumption of Tourism', Sociology, Vol. 24 No. 1, pp. 23-35.

Veblen, T. ([1899] 1931) The Theory of the Leisure Class: An Economic Study of Institutions, The Viking Press, Inc, New York.

Volo, S. (2009) 'Conceptualizing Experience: A Tourist Based Approach', Journal of Hospitality Marketing and Management, Vol. 18 No. 2-3, pp. 111-126.

Wilson, J. and Richards, G. (2008) 'Suspending Reality: An Exploration of Enclaves and the Backpacker Experience', in K. Hannam and I. Ateljevic (Eds.), Backpacker Tourism: Concepts and Profiles, Channel View Publications, Clevedon, pp. 9-25. 